\title{
Woven Webs: Trading Textiles around the Indian Ocean
}

\author{
Lola Sharon Davidson, University of Technology Sydney
}

Since ancient times, India has been a major exporter of textiles, sitting at the centre of a complex regional network of exchanges which inserted Indian cottons and silks as prestige items into the textile regimes of societies all around the Indian Ocean. The balance between indigenous production marking local identity and Indian imports marking elite status and trans-local identity was disrupted by the spread of the competing globalisations of Islam and Christianity. The European powers sought control over the production and movement of textiles as part of their larger struggle to dominate the trading system of the Indian Ocean. They expanded networks and forged new connections, redirecting a significant portion of production through metropolitan centres towards a global market and facilitating a dynamic process of cultural exchange. Within this new system particular networks continue to connect the disparate communities of the Indian Ocean and to play a complex role in negotiating identification with and resistance to competing globalisations.

\section{Trade networks of the ancient world}

The history of the textile trade is bedevilled by the fragility of its subject matter. Although we know from written sources that India was already a major manufacturer and exporter of textiles in ancient times, apart from a few fragments from archaeological sites, the oldest Indian textiles are $14^{\text {th }}$ century fabrics preserved in Indonesia (Maxwell 2003: 3). India’s textile dominance arose from two factors: abundant supplies of cotton and an early use of mordants to fix and vary vegetable dyes. To these advantages was added a plentiful supply of cheap, skilled labour. Herodotus (c. 
425 BCE) mentions Indian cotton while fragments from Egypt show that by the $3^{\text {rd }}$ century BCE a wide range of cotton cloth was being imported from India to supplement the local cotton and linen fabrics. Plain cotton came from northwest and southern India and Sri Lanka and finer cotton from the east coast and the Ganges valley (Wild \& Wild 2004).

The Periplus of the Erythraean Sea, a navigational and trade manual from the $1^{\text {st }}$ century CE, describes the trade route from Egypt through the Red Sea to India and as far down the African coast as modern Zanzibar (Prabha Ray 2004). This sea route complemented the north Arabian land route joining the Mediterranean to India and to China along the Silk Road. Although the Periplus mentions Indian cotton and silk, India's main exports to the West in the ancient period were not textiles but ivory, ebony and spices, the latter including a wide variety of substances but especially pepper and indigo, named by the Greeks for its land of origin (Balfour-Paul 2006: 360). In exchange India received Arabian resins and various metals, particularly gold. Control of the Spice Route gradually passed from the Nabataean Arabs to the Nestorian Christians of Persia who came to dominate trade in the northwest Indian Ocean and by the $7^{\text {th }}$ century had settled in Kerala and Tamil Nadu (Prabha Ray 2004: 22-23).

In the Eastern Indian Ocean trade was accompanied by a gradual diffusion of Indian religious and cultural influences from around the $3^{\text {rd }}$ century BCE. By the $4^{\text {th }}$ century CE Hindu kingdoms based on trade were flourishing in Java and among the Champa who dominated the coast of Vietnam. Whereas textiles exported from India to the Middle East and Mediterranean addressed a wide market and covered a full range of materials, from silks and the finest muslins to the coarsest of sailcloth, the eastern textile trade showed a high degree of market segmentation determined both by the textile regimes it encountered and the cultural context in which it had spread.

For the Austronesian cultures of Southeast Asia and the Indonesian archipelago, textiles held ritual as well as social importance. Weaving, specifically of continuous cloth on a back-strap loom, was a quintessentially female activity and textiles played an essential role in all rituals, where they represented the female principle needed to balance the male principle in order to achieve the ideal of harmony (Maxwell 1990: 74-76, 146; 2003: 4). Imported Indian textiles were also classified as female and were held in similarly high esteem, although they were not initially accorded the same ritual status 
(Maxwell 1990, 170-72, 214; Totton 2004). The consumption of Indian textiles formed part of a broader cultural influence in which Southeast Asian elites gradually adopted Hinduism and Buddhism together with Indian styles of dress and state organization (Maxwell 1990: 206-16). Traded for spices, Indian textiles served as visible manifestations of wealth and elite status. Rather than being absorbed as anonymous elements into a general market system, Indian textiles marked and defined courtly culture and its translocal connections.

Sometime between 200 BCE and 500 CE, seafarers from Borneo sailed their outrigger canoes across the Indian Ocean to settle Madagascar where their textile tradition continued its development in substantial isolation for several centuries (Kreamer \& Fee 2002; Kusimba, Odland \& Bronson 2004; Fee 2004: 85-90). As in Southeast Asia, textile production was women's work, ritually contrasted with the male work of agriculture and warfare (Fee 2002: 34-35). Cloth played a central symbolic role in all social exchanges, particularly between rulers and ruled, women and men, and the living and the dead. Women wove cotton, raffia and indigenous silk into a warp-striped cloth called a lamba which was used as either a skirt or a shawl. Blue-black and red, from indigo and madder, were the preferred colours. The back-strap loom and ikat (warpdyed) weaving with figurative designs are found nowhere else in Africa and point to the continuity of this tradition with South East Asia (Picton \& Mack 1989: 131-40; Peters n.d.; Kusimba et al. 2004).

At the very centre of the Indian Ocean, Sri Lanka was remarkable for its almost total absence of an indigenous textile tradition, doubtless due primarily to its proximity to India. All cloth for the traditional dress of sarong and sash was imported from India in exchange for Sri Lanka's exports of gemstones, rare woods, ivory, elephants and cinnamon. Sri Lanka itself produced only rough undyed cotton cloth, woven by a caste of astrologers and musicians. Attempts to establish a weaving industry on the island foundered upon the far higher status Sri Lankan Buddhist society accorded to agricultural pursuits (Cohen 2006).

By the $7^{\text {th }}$ century, control of the eastern route through to China was dominated by Srivijaya, a Buddhist maritime empire originally centred in Sumatra, which dominated the Sunda and Malacca Straits and extended throughout the greater part of the 
Indonesian archipelago and the Malay peninsula. Its wealth was based on long-distance trade and the levying of tolls on merchants (Totton 2004; Kerlogue 2004).

\section{The spread of Islam}

With the rise of Islam in the $7^{\text {th }}$ century, the new caliphates took over the network of the Nestorian Christians in the western Indian Ocean, and control of the spice (and textile) trade passed once again to the Arabs (Prabha Ray 2004). Islam spread to the trading settlements that the Swahili and Persians had established on the islands off east Africa, most notably Zanzibar, and from there traders moved on down the coast of Africa, exchanging Indian textiles for slaves, gold and ivory (Prabha Ray 2004: 22-24).

In Madagascar conversion to Islam was limited to relatively small numbers in the trading settlements on the northwest of the island. Imported Indian textiles were gradually adopted by the elite as signs of status but, lacking the wider cultural and religious associations that had accompanied these fabrics in Southeast Asia and the Indonesian archipelago, the imported textiles were accorded no particular symbolic value, and indigenous textiles continued to play the central role both in rituals and in everyday life.

Elsewhere the cultural practices associated with Islam affected the textile trade in a variety of ways. Slavery for domestic and sexual purposes played a central role in Islamic society and Indian textiles were needed both to purchase African slaves and to clothe them. The Islamic custom of veiling women increased the demand for fine cottons, as did the fashion for turbans, while the insistence on complete bodily covering for both sexes stimulated the demand for cloth overall. Shia law forbad men from indulging in the luxury of pure silk garments and this in turn increased the demand for silk-cotton mixes (Chaudhuri 1990: 307). Silk was nevertheless regarded as a higher status textile than cotton and continued to be preferred for clothing by those who could afford it.

The conversion of Gujarat in the $8^{\text {th }}$ century brought one of India's main textile areas under Muslim influence. In the course of time, the Islamic prohibition on depicting the human form and a consequent aversion to figurative art influenced the design of textiles, particularly those for export, by moving it away from sensuous depictions of the 
adorned human body towards geometric and floral motifs suited to the tastes of the expanding Muslim market (Zebrowski n.d.). Block printing made possible the mass production of patterned textiles imitating the decorative features of more expensive, labour-intensive cloth. Block printing was, moreover, particularly well suited to the repetitive geometric designs favoured by the Muslim market. The textile fragments found at Al Fustat suggest that a bulk trade in printed cottons developed throughout the Muslim world from Gujarat across to Egypt and thence to the Maghreb from where they filtered down to western Africa (Bérinstain n.d.). The technology of block printing also spread from Gujarat to the Muslim trading towns of East Africa, most notably Zanzibar. By the $13^{\text {th }}$ century the Shona of Greater Zimbabwe were spinning and weaving cotton, though not to an extent that could compete with imported textiles (Guille n.d.).

Further from Muslim influence, Coromandel stayed faithful to the pen and brush which remained the dominant medium for executing the elaborate devotional hangings depicting Hindu gods and goddesses which adorned Southern Indian temples (Gittinger n.d.). In any case religious conversion did not necessarily entail aesthetic transformation and traditions remained mixed in many areas. Under tolerant Muslim rulers, the Deccan kingdoms of Golconda and Hyderabad produced exquisite embroidered and painted temple hangings celebrating Krishna as well as Mughal-style miniature paintings (Safrani n.d.).

Muslim traders also ventured across the Indian Ocean towards China, trading Indian textiles for spices and spreading their religion. Southern China, already abundantly supplied with both cotton and silk, proved relatively indifferent to both, but in the Indonesian archipelago religion spread with trade (Kunz 2006). The northern tip of Sumatra converted to Islam towards the end of the $13^{\text {th }}$ century and was soon followed by the royal courts of Java. The last Hindu kingdom on Java fell at the end of the $15^{\text {th }}$ century, leaving the island of Bali as a Hindu outpost.

The conversion of much of the Indonesian archipelago to Islam was not immediately accompanied by profound cultural change. Traditional styles of dress and textile production were initially unaffected. Despite the change of religion, the courts long remained faithful to both the Indic ceremonies and the Indian textiles whose symbolism had been crucial to their process of state formation (Maxwell 2003). In Java, sumptuary laws prescribed which nobles were entitled to wear which designs. Court dress, 
characterised by the overall patterning typical of Indian cloth, was identical for males and females while the peasantry continued to wear striped homespun which expressed gender, age and group membership (Maxwell 1990: 218). Specific imported textiles enjoyed particular importance, chief of which was the double-ikat silk patola from Gujarat, a luxury fabric in which the tie-dying of both warp and weft threads permitted an extreme clarity of design. Block-printed and painted cottons were also imported from west India and the Coromandel Coast. There was some reciprocal influence in design since the prized patolas were imitated by Indonesian weavers while the Coromandel producers catered to their market with repetitive symmetrical designs in muted colours and by incorporating motifs such as the Balinese geringsing (Maxwell 2003; Kahlenberg 2006; Barnes 2006; Majilis 2006).

The block-printed cottons Gujarat exported to the West Asian and Indonesian markets exhibit general similarities, particularly in their use of standard motifs such as the floral roundel and the goose or hamsa (Guy 1998: 48-51; Riello \& Roy 2008: 4). However the very different roles they were allotted in the textile regimes of these two cultural areas, cheap material for tailored clothing and furnishing in the West, luxury status marker and ritual object in the East, inevitably led to a stylistic divergence. The Indonesian market came to favour a more sombre and densely packed decorative field, while the continued use of untailored wraps required borders and elaborate saw-toothed end sections (Maxwell 1990: 153, 218).

The Malays, already fond of silk Chinese jackets, adopted tailored tunics and turbans along with Islam but, outside the Malay Peninsula, Southeast Asia remained largely Buddhist, with court ceremonials echoing Brahminical Hinduism. Palaces were adorned with hangings depicting Indra surrounded by ethereal attendants, status and gender were exhibited in the particular cloths given and worn in systems of formalised exchange, royal agents commissioned court textiles with Siamese motifs and themes from the cloth-painters of Coromandel, and the king both controlled and profited from the lucrative trade in Indian textiles (Guy 2003). The Thais favoured maroons, blacks and dark red in grids with nervous white resist lines (Lemire 2009: 369). Indeed, the mere presence of a white border was sufficient to render cloth unsaleable to Malays, who scorned it as clearly destined for the Siamese market (Guy 1998: 67). 


\section{The impact of European colonialism}

The arrival of the Europeans in the Indian Ocean substantially increased the demand for Indian textiles both by opening up new markets and by intensifying trade with existing markets. It is claimed that when Vasco da Gama arrived in Calicut in 1498 some helpful North Africans took him aside and explained the Indian Ocean trading system to him. To buy pepper in Calicut he needed gold, which he could obtain from Kilwa in East Africa in return for textiles from Gujarat (Pomeranz \& Topik 1999: 228). For the Portuguese merchant adventurer the problem is obvious. What is he going to use to buy the textiles? Europe itself had always suffered from a lack of desirable resources to exchange for the fabled riches of the Orient. Europeans wanted spices but these could only be obtained from India in exchange for gold or from the Spice Islands in exchange for textiles. Europe itself produced an abundance of high quality textiles but plain, heavy woollens and sturdy linens initially held little appeal for a market accustomed to light, brightly coloured and decorated cottons and densely woven silk. In establishing their colonial empires, the European powers were competing for economic advantage but they were necessarily constrained by the existing systems of exchange.

In his Suma Oriental, written in India and Malacca between 1512 and 1515, Tomé Pires estimated that before the arrival of the Portuguese, Malacca received annually 5 vessels from Gujarat and Southern India plus several from Bengal, all laden with cloth. An idea of the scale and variety of this trade may be gathered from the comments of a Dutch observer almost a century later. In 1602, Augustin Stalpaert, surveying the market at Banda, by then the main market for spices in the archipelago, described 21 types of cloth from Coromandel, 8 from Gujarat and 6 from Bengal. Of the 70,000 pieces of cloth sold there annually, 85\% was Indian (Reid 2008: 36). The rest was Chinese silk or locally produced fabric, including silk from Aceh with a metallic supplementary warp design, which was traded back to India (Leigh 1989: 81). Pires further observed that 'Cambay chiefly stretches out two arms: with her right arm she reaches out towards Aden and with the other towards Malacca' (quoted in Pearson 2000: 125). By the time the Portuguese arrived, these two arms were operating independently and Indian Ocean trade had returned to its ancient segmentation. The Arabs, Turks and Persians stayed in the Arabian Sea, trading from Aden and Hormuz to Cambay in Gujarat, while the Chinese, whose move into the Indian Ocean had begun in the $12^{\text {th }}$ century and culminated in the enormous fleets of Zheng He in 1404 and 1433, had withdrawn into 
the South China Sea, trading only as far as Malacca, founded by a Srivijayan prince at the beginning of the fifteenth century. The intermediate trade was handled by Indian merchants, generally Gujaratis, who connected Cambay with Calicut, Coromandel and Southeast Asia. Victory at the Battle of Diu in 1509 established Portuguese domination of the Indian Ocean and by 1571 a string of forts and trading posts linked Lisbon with Nagasaki. Thus while clearly the most significant impact of the Portuguese in the Indian Ocean was their success in imposing restrictions on a previously free mercantile system through armed force, a secondary effect, noted by Om Prakash, was a limited resumption of long-distance maritime trade (Prakash 2000). Gujarati merchants still operated, but they were obliged to do so in Portuguese boats under the control of the Portuguese Crown and in competition with private traders from the Portuguese colonies.

The arrival of the English and Dutch brought an end to Portuguese domination of the Indian Ocean. The English East India Company (EEIC) was founded in 1600 and the Dutch Vereenigde Oost-Indische Compagnie (VOC) two years later. The EEIC initially followed the official Portuguese Estado strategy of focusing on the Asia-Europe trade while leaving the intra-Asian trade to private individuals, but the VOC immediately entered the intra-Asian trade, sourcing pepper, cloves, nutmeg and mace from the Indonesian archipelago in exchange for Indian textiles from Coromandel where they set up factories in 1606 and 1610. Before long the VOC's intra-Asian trade was as important as their Euro-Asian trade. The VOC adopted this strategy to solve the balance of payments problem. This had been less of a problem for the Portuguese who had been able to pay for their spices with silver from Japan and gold and silver from West Africa and South America. Following the expulsion of the Portuguese from Japan in 1639, the VOC took over selling silk and silk-cotton textiles from Bengal to Japan in exchange for bullion, as well as trading cotton and silk textiles from Coromandel and Gujarat for spices from the Indonesian archipelago for export to Europe.

Once in control of the Indonesian archipelago, the Dutch imposed a monopoly on the import of Indian textiles, ousting the Gujarati traders. They allocated textile quotas to indigenous rulers and, following established practice, used Indian textiles as gifts to create and cement alliances (Kerlogue 2004). In addition, the VOC is estimated to have used over a million pieces of cloth simply to clothe their slaves, quite apart from the cloth used to pay salaries, let alone that required for buying the spices themselves 
(Prakash 2009: 154). The Muslim sultans of Jambi in Sumatra, who had drawn their revenue from the spice-textile trade, resisted the Dutch by retreating upriver and using an overland route to continue their exchange of forest products for Indian textiles (Kerlogue 2004). Over time Dutch rule supplanted the local elites who had provided the main market for the imported textiles while plantation crops replaced the indigenous system of spice production which had paid for the textiles.

With the triumph of the Dutch in the archipelago, the Portuguese and the English shifted their focus westwards. Although there was some indigenous textile production in East Africa, most cloth was imported from Gujarat. Even so, Alpers has estimated that only 4 percent of the total export trade of western India went to East Africa (cited in Pearson 2000: 125). Most Gujarati cotton textiles went to the Persian Gulf, while the silk brocade patolas were specialist items for Southeast Asia. Nevertheless, particular towns in Gujarat, such as Jambusar, were totally dedicated to producing cloth for the East African trade in accordance with the specifications relayed back by the merchants (Machado 2008: 75). Cloth had long been a standard item of exchange for slaves in both East and West Africa and the growth of the slave trade from the sixteenth century greatly expanded this market. Although Portugal itself was not a cloth-producing nation, it dominated the coastal trade of West Africa from 1480 to 1540, exchanging Dutch, Flemish and English cloth for Moroccan cloth that could then be sold for gold and slaves in West Africa more cheaply than the trans-Saharan land route permitted (Vogt 1975: 635). Cloth functioned as the standard unit of currency in both East and West Africa - in the 1520s a slave cost between 20 and 24 cloths, defined as a piece of unbleached linen 3/4 yard in length (Vogt 1975: 648; Roberts 1996: 143). Following the death of Manuel I in 1521, conflict in northern Africa resulted in a shortage of textiles for the West African trade, so the Portuguese substituted Indian cottons (Vogt 1975). Both in response to growing demand and as a solution to the balance of payments problem, transhipped Indian textiles played an increasing role in this market (Subramanian 1998; Arasaratnam 1990). Spices, having a high price to volume ratio, left ample space aboard ship for a bulkier but still valuable commodity. Shipped round the Cape to Europe, Indian textiles were sold on to their established markets in Muslim North Africa, Turkey and the Levant, bypassing and to some extent undercutting, though never entirely replacing, the overland routes across Arabia, Persia and the Middle East (Marg n.d.: 83-84; Riello 2008a: 326). West Africans were particularly 
fond of blue, red and blue striped, and red and blue checked cottons which came to be known as Guinea cloth, although English red wool fabric continued to be popular and was often unravelled to provide material for indigenous weaving (Kriger 2009: 105-27; Roberts 1996). Guinea cloth, produced in Pondicherry, was the standard currency of Senegal in the $18^{\text {th }}$ century and the only product that could be exchanged for the gum that was essential for Europe’s own textile industry (Roberts 1996). Textiles made up $50 \%$ of the goods exchanged by French traders for slaves in 1755 and 1788 and comprised nearly 2/3 of England's exports to Africa during the $18^{\text {th }}$ century. Some of this cloth was linen and woollen cloth from Europe but a substantial portion was transhipped Indian cotton (Pomeranz \& Topik 1999: 228; Alpern 1995: 6-12, fns. 11 \& 34).

With greater exposure and a fall in price, Europeans too developed a taste for Indian textiles, particularly for colourfully decorated bedspreads. Whereas the first textiles sent back by the Portuguese from India had been Chinese silks purchased in Malabar, by the end of the $16^{\text {th }}$ century approximately 10 percent of the cargo shipped back to Lisbon consisted of textiles, predominantly Indian cottons (Riello 2008: 317). Until the 1660s, most of the textiles purchased by the VOC in India were for the Asian trade, but by the end of the century two-thirds were being sent to Holland (Prakash 2009: 152). The 1680s, in particular, saw a boom in exports of plain cotton and muslin from Bengal to England, as Indian production increased and tariffs against French goods rendered Indian fabrics more cost competitive. Bengal had traditionally produced finely woven cotton and silk-cotton mixes but its levels of production had always been far behind those of Coromandel and Gujarat. Expanding markets both lowered standards in the traditional textile producing areas, struggling to meet demand, and stimulated production in other regions. The eastern half of Bengal was still largely jungle in 1500, when the Portuguese started trading there, but by the late $17^{\text {th }}$ century Bengal had become the largest textile manufacturing region in the Indian subcontinent (Parthasarathi 2009: 41), while textiles had become the most important commodity traded by the chartered companies between Asia and Europe, supplanting the spices that had started it all (Riello 2008: 320; Riello \& Roy 2008: 6).

In 1700, concern for local production led the British to ban the import of Indian silk and silk-cotton fabrics. This merely caused an increase in imports of plain cotton fabric 
which was then printed in England. Another Act in 1720 duly prohibited the wearing of printed calico but allowed imports for transhipment. This led to Indian cloth being used predominantly for interior decoration and domestic clothing such as the banyan (Lemire 2009) but proved insufficient to stem the flood. In 1769 the weavers of Spitalfield rioted, leading to further protectionist legislation (Chaudhuri 1974). From 1689 to 1759, the French followed the English example and banned the import and wearing of Indian textiles while allowing transhipment (Lemire \& Riello 2003: 898; Riello 2008: 322-23). Indian cloth made up $3 / 4$ of the cargo brought back by the French East India Company and accounted for almost 30\% of its profits. Australia, too, provided an enthusiastic, if small, market for Indian textiles from European settlement in 1788 until the imposition of trade restrictions in the 1830s (Broadbent 2003).

The shift to plain cotton marked an innovation in the Indian textile trade, as previously all fabric for export had been printed, dyed or decorated in some fashion (Parthasarathi 2009). Europeans also manifested a strong preference for white backgrounds, again contrasting with the Asian and African markets which favoured a completely coloured field. Moreover, whereas the Southeast Asian market had been profoundly conservative, in deference to the ritual and status role of the textiles, Europeans, like Africans, were fickle and individualist. They insisted on a wide variety of fabrics and changed fashion annually (Chaudhuri 1974: 266; Machado 2008: 66). Sample patterns were sent from England to agents in India and a hybrid decorative style developed which in its enthusiasm for floral motifs and depiction of birds and animals complemented the tastes of the Muslim courts of the Mughals and the Deccan while simultaneously appealing to the enthusiasm for nature that was an essential aspect of $19^{\text {th }}$ century European Romanticism (Lemire \& Riello 2008: 894).

Not only cotton and silk but also Indian wool shawls were fashionable in Europe, Russia and the Ottoman Empire throughout the $18^{\text {th }}$ and $19^{\text {th }}$ centuries. The most luxurious were the Kashmiri shawls woven from the under-fleece of the Himalayan mountain goat and decorated with an ancient Persian motif called a boteh. Attempts to produce equally fine wool in Europe failed but in the 1780s Edinburgh and Norwich started producing cheaper imitations of the prized shawls. The introduction of the Jacquard loom to the Scottish town of Paisley in the 1820s made its name synonymous with both the motif and the shawls featuring it, though this mass production did not 
displace the luxury end of the market. Indian shawls and their Scottish imitations were a popular accompaniment to the neoclassical empire line dresses of fine muslin and silk fashionable from the 1790s to the 1820s but fell somewhat from favour when women's dresses moved to the fuller shape of the crinoline in the 1830s and then to the bustle in the 1870s (Reilly 1987; Rizvi 2006).

A combination of protectionism and technological innovation encouraged European manufacturers to imitate Indian textiles for both local and export markets (Lemire \& Riello 2003: 897-905). As the Industrial Revolution took off in England, India became the main source of raw cotton for the Lancashire textile mills and the United States, benefitting from slave labour and a superior indigenous form of cotton, emerged as a competitor. By 1820, English cotton had supplanted Indian chintzes for everyday dress throughout Southeast Asia, with over half of the trade being in white cotton for use in making batik (Reid 2008: 46). Batik, which is first mentioned in the $17^{\text {th }}$ century, adapted Indian print designs to local Javanese tastes. The wax-resist dying of the fabric, as opposed to its weaving, became an important cultural practice, employing a particular imagery and muted tonal range expressing both abundance and self-restraint. Batik became a characteristically Javanese cultural product (Maxwell 1990: 325-27). Once milled cotton became available, locally dyed material undercut the Indonesian market for Indian textiles. By the $19^{\text {th }}$ century, imitation Indian chintz was being produced in northern Java (Kerlogue 2004). Men moved into commercial textile production which had previously been an exclusively female, and ritually significant, occupation (Maxwell 1990: 404). The ancient dichotomy between imported cloth expressing elite status and indigenous cloth expressing local and ritual status, together with the classification of all cloth as ritually female, gave way to the use of batik as a signifier of national and cultural identity (Maxwell 2003: 145ff).

\section{Weaving identities}

The circuits of communication opened up by colonialism, combined with the tensions it created, enlarged the role of textiles as dynamic signifiers of changing cultural identities, negotiating the balance between local identity and the competing globalisations of Islam and the West. Decoratively, Islam and Europe pulled in opposite directions, the former towards abstract design, the latter towards natural realism (Maxwell 1990: 328-29, 377-93). On the other hand, their modesty conventions converged, leading to the 
adoption of bodices for women, tunics for men and jackets for both sexes, although the basic rectangular sarong that had served as dress around the Indian Ocean for so long initially remained unaltered. By the late 1880s, elite Indian males wore European dress in public combined with Indian headgear while females remained faithful to the Hindu sari and the Muslim kurta pyjama (Prabha Ray 2004). In 1869, King Chulalongkorn of Siam Europeanised court dress and by the late $19^{\text {th }}$ century observers in northern Thailand noted that the traditional sarong and scarf were being supplemented with jackets by both sexes (Guy 2003: 80; Bowie 1992: 819). At the same period, Siamese noblewomen took to weaving their own silk brocade wraps, partly as an assertion of cultural superiority and partly in response to a decline in the quality of Indian and Chinese silks which were increasingly targeted at a mass market (Guy 1998: 147-50). For the lower classes, English towels competed with Bombay shawls as preferred scarves and were still popular for sashes and turbans in Nepal in the 1970s. In both Indonesia and Madagascar, the shift to tailoring meant a rejection of the reverence for the uncut cloth produced by the traditional back-strap loom.

In the mid- $20^{\text {th }}$ century, the government of the Maldives prescribed European dress for male public servants while offering women the choice of two dress styles, one Muslim and one European, but both obeying Islamic codes of modesty (Maloney 1980: 171-74). The bare breasts that so offended Ibn Battuta, along with the fine textiles that so impressed him, are a distant memory. Throughout the Indian Ocean region, both sexes have tended to adopt European styles for everyday and work wear while reserving traditional dress for domestic and ceremonial occasions. Alternatively males wear European dress while females wear modified versions of Islamic dress or else express an ambivalent adherence to Islam and the West by wearing headscarves with Western clothes. The spread of Western clothing has been further promoted by the trade in second-hand clothes, donated to charities and sold in underdeveloped nations, incidentally undermining local textile production. Used clothing and linen played a minor role in European exports to Africa from the earliest period but the scale of this trade has grown as charities have transformed themselves into international businesses (Vogt 1975: 646-47; Alpern 1995: 11). At the same time transhipment and imitation have nurtured new networks. As travel has become accessible to larger numbers of people the haj has become a significant circuit of textile distribution. Many of the textiles brought back from the markets of Mecca by pilgrims are produced in India. 
Their trajectory through the sacred space adds to their cultural value and they are accordingly treasured and imitated in their ultimate destinations throughout the Islamic world. Couched velvet embroidered with gold and silver thread is a particular favourite in this trade (Kerlogue 2004).

Gandhi's call for the boycotting of English textiles and the wearing of homespun as part of the Indian independence movement is probably the most famous example of political power expressed through clothing. Further from the shores of the Indian Ocean, Tibetans manifested their opposition to Chinese domination by their preference for Indian brocade which began replacing the imported Chinese version in the mid- $19^{\text {th }}$ century when Tibetan monks commissioned it from Muslim weavers in Benares (Ahmed 2006; Graham 2006). During the $17^{\text {th }}$ century, women of the Merina tribe in the Madagascan highlands responded to imported cloth by weaving silk wraps for export to the rest of the island (Fee 2004; Fee 2002: 46). This coincided with an extension of Merina's political influence, expressed in part by gifts of this cloth to subordinate chiefs. In the $19^{\text {th }}$ century, Merina commoners dressed in American white cotton as a sign of free status while the rulers used red English broadcloth and Indian red silk parasols. Other ethnic groups, particularly the Betsileo, affirmed their independence from Merina by continuing to dress in cloth made from hemp, bark and raffia. As the pressure of European colonisation increased, the Merina court changed its dress style from European to Arabic (Fee 2004). After the French takeover in 1883, Merina nobles stopped wearing red and reserved the royal colour for shrouding the dead, again using cloth to express their resistance to foreign domination (Fee 2002: 51). Following independence, the traditional silk lamba was revived as a shawl to provide a luxurious indigenous accessory to Western clothing.

Just as the Indonesians had adapted Indian textile motifs for local production, the Dutch appropriated Indian and Indonesian motifs for use on printed, machined cloth that they then exported to other colonies, a strategy also followed by the British. The Haarlem Cotton Company made the first attempt at imitating Javanese batik following the Napoleonic Wars. The Javanese were unimpressed, so the Dutch sold their prints to a Glasgow merchant, Ebenezer Brown Flemming, who shipped them to West Africa. Flemming then developed and patented designs which incorporated West African motifs, such as Ashante swords and proverbs, into Indonesian batik designs. His British 
successors expanded the repertoire to include prints commemorating significant events. Meanwhile, by the end of the $19^{\text {th }}$ century the Dutch had developed a separate market in East Africa where German traders in Mombasa, Dar es Salaam and Zanzibar commissioned textiles with large-scale motifs in bright, contrasting colours, unlike those previously imported from India but closer to indigenous aesthetic traditions. These European textiles, printed to suit specific markets, undercut Indian textiles in Africa and, indeed, swamped local production until the establishment of textile mills towards the end of the $20^{\text {th }}$ century (Picton n.d.). Inland from the coast, the Masai continue to affect distinctive dress while rejecting both Islam and Christianity. Their tourist paintings invariably show them clad in the single red woollen blankets originally imported from England, although they now drape themselves in an average of four lengths of thick striped or checked cotton, called shuka, which is produced locally for sale to both the Masai and the tourists.

The Gujarati wood-block prints have a more direct East African descendant in the kanga. This female garment, consisting of two matching pieces of rectangular cloth, was dubbed guinea-fowl in Kiswahili, because the original kangas were speckled black, white and red. They were first produced on the Swahili coast around Zanzibar in the 1850s in imitation of textiles from Kutch imported by Muslim traders. They have a symmetrical design with a central motif and a border featuring writing. A Sunni Muslim from Sindh, Abdullah Essah, who set up in Mombasa in 1887, claimed to be the first to print sayings on the cloths, using Arabic proverbs. However, from the early $20^{\text {th }}$ century the sayings have been in Kiswahili using Roman script and the nature of the messages has become personal and explicitly sexual (Parkin 2004). Women aspire to possess as many kanga as possible and employ them as a form of indirect communication where direct statements would be socially inappropriate (Hamid n.d.). Attempts to ban the kanga have been unsuccessful. As in West Africa, commemorative designs are also popular and are commissioned by political and social parties. Local production suffered from foreign competition but has revived with the introduction of rotary print mills and the main competition now is from Indian silk-screen printed cloth (Hilger n.d.). The kanga is made of very thin cotton so can be worn as casual dress for the home or can be draped over other clothing as a form of veiling, an alternative to the head-to-foot black buibui or the Arabian hijab for wear in public. Thus it simultaneously asserts both Islamic identity and local identity while enacting a paradox between Islamic demands 
for female modesty and Swahili traditions of sexual expressiveness. The Islamic identity of the kanga has been weakened due to its adoption by non-Islamic women as a local alternative or decorative supplement to Western dress and this in turn has led to an Arabisation of outdoor dress among wealthier Islamic women (Parkin 2004).

RMHK, or Real Madras Handkerchief, also known as George, from Fort George, was a cotton plaid dyed with indigo and madder produced in Andhra Pradesh and exported from Chennai to England from where it was sent to West Africa to exchange for slaves, gold, ivory and palm oil. A Swiss firm developed an industrial imitation for the same market. At the beginning of the $20^{\text {th }}$ century, the Swiss firm and an English competitor opened branches in Chennai and then, a few decades later, in Nigeria. This resulted in a more effective flow of information about stylistic preferences. After the Second World War a new version of George was introduced, RMHK Fancy, which paradoxically left a plain space to be filled with embroidery in Africa in accordance with local Islamic traditions. Trade boomed until 1976 when the Nigerian government banned textile imports, throwing 30,000 Indian hand-loom weavers out of work. The trade continued clandestinely until import restrictions were eased. The West African market women then made their way to Chennai to place their orders directly. They brought velvets embroidered with metal thread in the Islamic style, which they wanted copied and which joined George as the staple of the India-West Africa textile trade. By this stage, the English and Swiss firms had merged and passed into Indian ownership. The elimination of the European middleman has led to a blending of West African and Indian designs (Lutz 2006). Nevertheless the original Indian textiles remain symbolically important, at least for some groups. The Kalabari, a tribe in the Niger Delta, regards George as the most valuable textile and uses it both for clothing and ceremonial purposes. They never wear the printed cotton cloth popular with neighbouring ethnic groups. The mother and baby are wrapped in George and for a funeral the mourners wear George and three successive rooms are decorated, the first with George, the second with hand-loomed West African textiles, and the third with Islamic embroidered velvets (Eicher 2006), achieving thereby a threefold identification.

The homogenizing effect of international trade is undeniable. The tourist shops of Zanzibar sell the same Europeanised clothes from India as do the shops of Delhi, Singapore and Sydney. Cushion covers with designs copied from the Spanish painter 
Miro are chain-stitched to order in Kashmir and sold over the internet to the world. Indigenous textile production continues to sustain local identity in groups resistant to globalising forces, such as the many tribal groups still existing in the Indian Ocean region. The numerous non-Vietnamese ethnic groups of Vietnam, for example, continue to produce and wear indigo-dyed cloth decorated with appliqué and embroidery (Vietnam Museum of Ethnology 1981). For many of these groups, sale of their textiles to outsiders is a major source of income and even the continued local consumption for clothing is increasingly linked to the global phenomenon of mass tourism and the commodification of ethnic identity. These ethnic textiles follow international trade routes of their own, passing through middlemen to the national market and thence to the global market while at the same time buyers, in the form of tourists, come from the other side of the world to purchase the goods at source. The trade in ethnic textiles is minuscule in the context of the textile trade as a whole, but its association with cultural identity and with the global tourist market endows it with significance beyond its material or commercial size. Bhutan offers 14-day weaving tours; Luang Prabhang hosts a nightly market displaying a fabulous array of hand-made textiles, mixing the traditional with those adapted to more modern tastes; the Hmong have little to offer beyond their elaborately dyed and embroidered costumes, but these are now recycled by traders as jackets and backpacks for tourists.

Textiles, their production, their display and their ritual uses, remain potent ways of creating and expressing ethnic identity. The Malaysian government sponsors craft production of batik and songket, textiles associated with traditional Malay court culture whose adoption as national symbols asserts the dominance of Malays as definers of national identity at the expense of other ethnic groups, such as the Chinese or Indians. Malaysian batik, which dates from the 1920s, differs from Indonesian batik in both technique and design — it is painted rather than resist-dyed, more colourful and predominantly floral. Only government protection prevents it being swamped by the cheaper product from its more populous neighbour. Songket, a silk fabric with metallic supplementary warp, was associated with the Malay sultanates from the $16^{\text {th }}$ century. Both fabrics now feature as formal dress and in tourist promotion (Leigh 2000 \& 2002).

It is not only nations that pursue such a strategy. The Kedang of eastern Indonesia were a non-weaving tribe who exchanged forest products for ceremonial textiles with one 
neighbour and for everyday textiles with another, a pattern repeated throughout their immediate region and that, moreover, reproduced the original structure of the Indian Ocean textile trade. In recent years, a Kedang woman with connections to both neighbouring groups has not only introduced weaving to her village but has developed 'traditional' costumes for both men and women. These costumes are now worn for the animist ceremonies in honour of the ancestors, ceremonies that themselves have been greatly expanded, in particular to include the use of these new 'traditional' textiles (Barnes 2004b).

Throughout its long history, the changing networks of the Indian Ocean textile trade have served as circuits of material communication, transmitting cultural values embodied in cloth, defining and redefining identities and relationships. Coloured cottons and fine muslins to drape Greco-Roman ladies, double-ikat silk patolas and painted Coromandel cottons for the courts of South-east Asia, block-printed Gujarati cottons for the markets of North Africa and the Middle East, fine cottons for the veils of Muslim women and the floating neo-classical gowns of European women, coarse blue cloth to clothe African slaves and blue and red checked and striped cotton to buy them with, floral motifs with birds and animals for the Mughal courts and the European Romantics, cashmere shawls for Europe, Russia and the Ottoman Empire: all these textiles participated in a process of cultural exchange that altered fashions and hence material cultural expressions. The uncut cloth of the Austronesians yielded to tailoring and full bodily covering, patolas and block prints gave birth to Indonesian batik, cashmere shawls transmuted to paisley, Gujarati block-prints were enlarged and exaggerated for East African tastes and adorned with Arab proverbs to create the kanga, and Indian and Indonesian motifs contributed to the West African cotton print. Even as Western clothing styles become ever more ubiquitous, the multifarious networks of the Indian Ocean textile trade continue to sustain the creation of cultural identities in an interconnected world.

\section{Reference List}

Ahmed, M. 2006, 'Brocade for the Buddhists: The textile trade between Benares and Tibet,' in Textiles from India: The Global Trade (ed.) R.y Crill, Seagull, Oxford, 9-26.

Alpern, S.B. 1995, 'What Africans Got for their Slaves: A Master List of European Trade Goods,' History in Africa, vol. 22: 5-43. 
Arasaratnam, S. 1990, 'Weavers, Merchants and Company: The Handloom Industry in South-eastern India, 1750-1790,' in Merchants, Markets and the State in early Modern India (ed.) S.

Subrahmanyam, Oxford University Prses, Delhi, 190-214.

Balfour-Paul, J. 2006, 'India’s Trade in Indigo: Its Ups and Downs' in Textiles from India: The Global Trade (ed.) R. Crill, Seagull, Oxford, 357-74.

Barnes, R. (ed.) 2004a Textiles in Indian Ocean Societies, Routledge, New York. 2004b 'Moving Between Cultures: Textiles as a Source of Innovation in Kedang, Eastern Indonesia,' in Textiles in Indian Ocean Societies (ed.) R. Barnes, Routledge, New York, 150-62. 2006 'Indian Textiles for Island Taste: The Trade to Eastern Indonesia,' in Textiles from India: The Global Trade, (ed.) Rosemary Crill, Seagull, Oxford, 99-116.

Bérinstain, V. n.d., 'Early Indian Textiles Discovered in Egypt,' in Marg, vol. 40, no. 3: 'Legendary Themes of Weavers and Dyers-Textiles of India and Persia,' 16-24.

Bowie, K.A. 1992 'Unravelling the Myth of the Subsistence Economy: Textile Production in NineteenthCentury Northern Thailand,' The Journal of Asian Studies, vol. 51, no. 4: 797-823.

Broadbent, J. 2003, 'A Survey of Colonial Imports: Textiles and Costume' in India, China, Australia: Trade and Society 1788-1850, (eds) J. Broadbent, S. Rickard \& M. Steven, Historic Houses Trust of NSW, Sydney, 155-64.

Chaudhuri, K.N. 1990, Asia before Europe: Economy and Civilisation of the Indian Ocean from the Rise of Islam to 1750, Cambridge University Press, Cambridge.

Chaudhuri, S. 1974, 'Textile Trade and Industry in Bengal Suba, 1650-1720,' Indian Historical Review, vol. 1, no. 2: 262-75.

Cohen, S. 2006, 'The Unusual Textile Trade between India and Sri Lanka: Block Prints and Chintz 15501900,' in Textiles from India: The Global Trade, (ed.) R. Crill, Seagull, Oxford, 56-80.

Crill, R. (ed.) 2006, Textiles from India: The Global Trade, Seagull, Oxford.

Eicher, J.B. 2006, 'Kalabari Identity and Indian Textiles in the Niger Delta,' in Textiles from India: The Global Trade (ed.) R. Crill, Seagull, Oxford, 153-71.

Fee, S. 2002, 'Cloth in Motion: Madagascar's Textiles through History,' in Objects as Envoys: Cloth, Imagery and Diplomacy in Madagascar, (eds) C. M. Kreamer \& S. Fee, Smithsonian Institute, University of Washington Press, Seattle, 32-93. 2004, 'Ze mañeva aze: Looking for Patterns in Malagasy Cloth,' in Textiles in Indian Ocean Societies, (ed.) R. Barnes, Routledge, New York, 85-109.

Gittinger, M. n.d., 'Ingenious Techniques in Early Indian Dyed Cotton,’ in Marg, vol. 40, no. 3 'Legendary Themes of Weavers and Dyers—-Textiles of India and Persia, 4-15.

Graham, J. 2006, 'The Contemporary Use of Gyasar Brocade in Qinghai Province, China (Amdo, Tibet), in Textiles from India: The Global Trade (ed.) R. Crill, Seagull, Oxford, 27-38.

Guille, J. n.d., 'Southern African Textiles Today: Design, Industry and Collective Enterprise,' in The Art of African Textiles: Technology, Tradition and Lurex, (ed.) J. Picton, Lund Humphries Publishers, London, 51-54.

Guy, J. 1998, Woven Cargoes: Indian Textiles in the East, Thames \& Hudson, New York. 2003, 'Fit for a King: Indian Textiles and Thai Court Protocol,' Arts of Asia, vol. 33, no. 2: 70-81.

Hamid, M.A. n.d., Kanga: More than What Meets the Eye; A Medium of Communication, Tanzania Media Women's Association, Dar es Salaam.

Hilger, J. n.d., 'The Kanga: An Example of East African Textile Design,' in The Art of African Textiles: Technology, Tradition and Lurex, (ed.) J. Picton, Lund Humphries Publishers, London, 44-45.

Kahlenberg, M.H. 2006, 'Who Influenced Whom? The Indian Textile Trade to Sumatra and Java,' in Textiles from India: The Global Trade, (ed.) Rosemary Crill, Seagull, Oxford, 135-50.

Kerlogue, F.A. 2004, 'Textiles of Jambi (Sumatra) and the Indian Ocean Trade,' in Textiles in Indian Ocean Societies, (ed.) R. Barnes, Routledge, New York, 130-49.

Kreamer, C.M. \& Fee, S. (eds) 2002, Objects as Envoys: Cloth, Imagery and Diplomacy in Madagascar, Smithsonian Institute, University of Washington Press, Seattle.

Kriger, C.E. 2009, 'Guinea Cloth’: Production and Consumption of Cotton Textiles in West Africa Before and During the Atlantic Slave Trade,' in The Spinning World: A Global History of Cotton Textiles, 1200-1850,(eds) G. Riello \& P. Prasarathi, Oxford University Press, Oxford, 105-27.

Kunz, R. 2006, 'Bengali Textiles as Tribute Items to Ming China,' in Textiles from India: The Global Trade, (ed.) R. Crill, Seagull, Oxford, 39-55. 
Kunz, R. \& Riello, G, 2008, 'East and West: Textiles and Fashion in Early Modern Europe,' Journal of Social History, vol. 41, no. 4, Summer: 887-916.

Kusimba, C.M., Odland, J.C. \& Bronson, B. (eds) 2004, Unwrapping the Textile Traditions of Madagascar, Field Museum \& UCLA, Fowler Museum of Cultural History Textile Series No. 7, Los Angeles.

Leigh, B. 1989, Hands of Time: The Crafts of Aceh, Djambatan, Jakarta. 2000, The Changing Face of Malaysian Crafts: Identity, Industry, and Ingenuity, Oxford University Press, New York. 2002, 'Batik and Pewter: Symbols of Malaysian Pianissimo,' Sojourn: Journal of Social Issues in Southeast Asia, vol. 17, no. 1: 94-109.

Lemire, B. 2009, 'Fashioning Global Trade: Indian Textiles, Gender Meanings and European Consumers, 1500-1800,' in How India Clothed the World: The World of South Asian Textiles, 1500-1850, (eds) G. Riello \& T. Roy, Brill, Leiden, 365-89.

Liu, X. 1996, Silk and Religion: An exploration of Material Life and the Thought of People, Oxford University Press, Delhi.

Lutz, H. 2006, 'Changing Twentieth Century Textile Design and Industry Structure in the India-West Africa Embroidery Trade,’ in Textiles from India: The Global Trade (ed.) R. Crill, Seagull, Oxford, 172-94.

Machado, P. 2008, 'Cloths of a New Fashion: Networks of Exchange, African Consumerism and Cloth Zones of Contact in India and the Indian Ocean in the Eighteenth and Nineteenth Centuries,' in How India Clothed the World: The World of South Asian Textiles, 1500-1850, (eds) G. Riello \& T. Roy, Brill, Leiden, 53-84.

Majilis, B.K. 2006, 'In Quest of Patterns: Notes on a Group of Indian Trade Textiles from the Treasury of the Raja of Los Palos in East Timor,' in Textiles from India: The Global Trade, (ed.) R. Crill, Seagull, Oxford, 117-34.

Maloney, C. 1980, People of the Maldive Islands, Orient Longman, Madras.

Marg n.d. 'The Romance of Indo-European Textile Trade,' Marg vol. 33, no. 1: 'Warp and Woof, Historical Textiles, Calico Museum, Ahmedabad,' 81-96.

Maxwell, R. 1990, Textiles of Southeast Asia: Tradition, Trade and Transformation, Australian National Gallery, Oxford University Press, Oxford. 2003, Sari to Sarong: Five Hundred Years of Indian and Indonesian Textile Exchange, National Gallery of Australia, Canberra.

Parkin, D. 2004, 'Textile as Commodity, Dress as Text: Swahili Kanga and Women’s Statements,' in Textiles in Indian Ocean Societies, (ed.) Ruth Barnes, Routledge, New York, 47-67.

Parthasarathi, P. 2009, 'Cotton Textiles in the Indian Subcontinent, 1200-1800' in The Spinning World: A Global History of Cotton Textiles, 1200-1850, (eds) G. Riello \& P. Prasarathi, Oxford U.P., Oxford, 17-41.

Pearson, M.N. 2000, 'The East African Coast in 1498: A Synchronic Study, in Vasco da Gama and the Linking of Europe and Asia (eds) A. Disney \& E. Booth, Oxford University Press, New Delhi, 116-30.

Peters, S. n.d. 'Weaving in Madagascar,' in The Art of African Textiles: Technology, Tradition and Lurex, (ed.) J. Picton, Lund Humphries Publishers, London, 46-47.

Picton, J. (ed.) n.d., 'Technology, Tradition and Lurex: The Art of Textiles in Africa,' in The Art of African Textiles: Technology, Tradition and Lurex (ed.) J. Picton, Lund Humphries Publishers, London, 9-31.

Picton, J. \& Mack, J. 1989, African Textiles, British Museum, London.

Pomeranz, K. \& Topik, S. 1999, The World that Trade Created: Society, Culture and the World Economy, 1400-the Present, M.E. Sharpe, New York.

Prabha Ray, H. 2004, 'Far-flung Fabrics-Indian Textiles in Ancient Maritime Trade,' in Textiles in Indian Ocean Societies, (ed.) R. Barnes, Routledge, New York, 17-37.

Prakash, O. 2000, 'The Portuguese in the Far East, 1540-1640,' in Vasco da Gama and the Linking of Europe and Asia, (eds) A. Disney \& E. Booth, Oxford University Press, New Delhi, 131-41. 2009, 'The Dutch and the Indian Ocean Textile Trade,' in The Spinning World: A Global History of Cotton Textiles, 1200-1850, (eds) G. Riello \& P. Prasarathi, Oxford University Press, Oxford, 145-60. 
Reid, A. 2008, 'Southeast Asian Consumption of Indian and British Cotton Cloth, 1600-1850,' in How India Clothed the World: The World of South Asian Textiles, 1500-1850 (eds) G. Riello \& T. Roy, Brill, Leiden, 31-51.

Reilly, V. 1987, The Paisley Pattern, Richard Drow, Glasgow.

Riello, G. 2008, 'The Indian Apprenticeship: The Trade of Indian Textiles and the Making of European Cottons,' in How India Clothed the World: The World of South Asian Textiles, 1500-1850, (eds) G. Riello and T. Roy, Brill, Leiden, 309-46.

Riello, G., \& Roy, T. (eds and intro.) 2008, How India Clothed the World: The World of South Asian Textiles, 1500-1850, Brill, Leiden.

Rizvi, J. 2006, 'The Asian Trade in Kashmir Shawls,' in Textiles from India: The Global Trade (ed.) R. Crill, Seagull, Oxford, 81-98.

Roberts, R. 1996, 'West Africa and the Pondicherry Textile Industry,' in Cloth and Commerce: Textiles in Colonial India (ed.) T. Roy, Sage, Delhi, 142-74.

Roy, T. (ed.) 1996, Cloth and Commerce: Textiles in Colonial India, Sage, Delhi.

Safrani, S.H. n.d., 'Golconda Picchwais: Expressions of Devotion,' in Marg vol. 44, no. 1: 'The Qutb Shahs of Golconda,' 29-44.

Subramanian, L. 1998, 'Power and the Weave: Weavers, Merchants and Rulers in Eighteenth Century Surat,' in Politics and Trade in the Indian Ocean World: Essays in Honour of Ashin Das Gupta (eds) R. Mukherjee \& L. Subramanian, Oxford University Press, Delhi, 52-82.

Totton, M.L. 2004, 'Cosmopolitan Tastes and Indigenous Designs-Virtual Cloth in a Javanese Candi,' in Textiles in Indian Ocean Societies (ed.) R. Barnes, Routledge, New York, 109-29.

Vietnam Museum of Ethnology 1981, Catalogue, Vietnam Museum of Ethnology, Hanoi.

Vogt, J. 1975, 'Notes on the Portuguese Cloth Trade in West Africa, 1480-1540,' The International Journal of African Historical Studies, vol. 8, no. 4, 623-51.

Wild, J.R. \& Wild, F. 2004, 'Rome and India: Early Indian Cotton Textiles from Berenike, Red Sea Coast of Egypt,' in Textiles in Indian Ocean Societies, (ed.) R, Barnes, Routledge, New York, 11-16.

Zebrowski, M. n.d., 'The Hindu and Muslim Elements of Mughal Art with Reference to Textiles,' in Marg, vol. 40, no. 3: 'Legendary Themes of Weavers and Dyers-Textiles of India and Persia,' 26-35. 